\title{
The two stabilities: Friends, good friends, or inseparable?
}

\author{
Forrest Capie $^{1} \cdot$ Terence C. Mills $^{2} \cdot$ Geoffrey Wood $^{3}$
}

Published online: 3 November 2018

(C) The Author(s) 2018

\begin{abstract}
Throughout his long and distinguished career, David Mayes was concerned with a wide range of subjects. This paper focuses on three of them: on monetary and financial history, on monetary stability, and on financial stability. We use the first of these to open up exploration of the second and third. A relationship is often asserted between monetary and financial stability, but how close and how durable is it? Is it one that holds through a long span of history, or is it contingent on a range of factors and therefore comes and goes? To address this, we use here data exclusively from Britain.
\end{abstract}

Keywords Monetary policy · Financial stability $\cdot$ Central banking

JEL Classification E42 $\cdot$ E52 $\cdot$ E58

\section{Introduction}

Throughout his long and distinguished career, David Mayes was concerned with a wide range of subjects. This paper focuses on three of them: on monetary and financial

We are indebted to Dr. Juan Castaneda of the University of Buckingham for his assistance with this paper.

Forrest Capie

f.h.capie@city.ac.uk

1 Emeritus Professor of Economic History, Cass Business School, London, UK

2 University of Loughborough, Loughborough, UK

3 Emeritus Professor of Economics, Cass Business School, London, UK history, on monetary stability, and on financial stability. We use the first of these to open up exploration of the second and third. A relationship is often asserted between monetary and financial stability, but how close and how durable is it? Is it one that holds through a long span of history, or is it contingent on a range of factors and therefore comes and goes? To address this, we use here data exclusively from Britain.

There are several reasons for this. While cross-country comparison may well be valuable in future work, concentrating on Britain allows a reasonable degree of brevity. That may be regarded as, so to speak, a negative advantage; it stops the paper being too long and turning into a pamphlet or even a monograph. There are also important positive advantages. Concentrating on Britain means that the paper can use a long and well-understood set of data. These data cover numerous exchange rate and money supply regimes, as well as various banking system structures, a variety of types of behaviour with regard to the stability of the banking system by the central bank, and a variety of bank regulatory and supervisory approaches. In addition, the Bank of England was the model for a good number of central banks around the world, so what we find for the significance of the Bank's behaviour can be extended as an initial hypothesis, in subsequent work, to several central banks, and indeed the same conclusions can be assumed to hold until otherwise is shown.

This inductive procedure is in the tradition of David Hume. $^{1}$ That is, we observe the world and find some relationships suggested and decide to test the suggested hypothesis on available data.

\footnotetext{
${ }^{1}$ For a contemporary exposition of this procedure see Gottlieb (2001).
} 


\section{Why price stability matters for financial stability}

When engaged in borrowing and lending, banks need to hold both capital and liquidity. They need these because banks can fail from loss of liquidity, so that they cannot pay out depositors' funds as demanded, or from loss of capital, so that they can no longer pay out depositors because their money has been lost through lending which turns out bad even though perhaps made with great caution. $^{2}$

If the future behaviour of the price level is not reasonably predictable, it is harder to judge the likely future value of collateral, of investment projects for which borrowing is requested, and the ability of unsecured creditors to repay from income at some time in the future. Anna Schwartz explored these matters in detail in a 1988 paper [1], and that is the essence of the argument that price stability reinforces financial stability.

Capital comprises funds the bank actually owns. It can be provided by the bank's shareholders, or, depending on the corporate form, the partners in the bank or even by its sole owner. Such funds are needed because regardless of how well the bank is run, how well it treats its customers, and how well aware it is of its responsibilities to them, now and again it will lose money on a loan. Some or all of what it has lent will not be paid back. That, though, is no excuse (in either morality or law) for not repaying the people who have lent the bank money; so the bank needs some funds of its own to make up what is needed to repay depositors when that is necessary.

The failure through loss of liquidity is also important. Indeed, it is in some ways more important, for failure through loss of liquidity can happen much more rapidlynot even overnight, but between breakfast and lunch.

Liquidity is in some ways a rather trickier concept than capital. It can first of all, and most easily, be thought of as cash the bank keeps in its own vaults. Some cash is needed because while payments into the bank match withdrawals most of the time, sometimes they fall short. Again, the bank is obliged to pay out what customers demand, so to avoid default and consequent closure they need some cash in hand.

How much cash banks need depends, it is worth emphasising, inter alia on the attitude of the relevant central bank to supplying cash. The central bank may be willing to lend short term, on non-penal terms, on a wide range of securities as collateral. In such circumstances, an individual bank need hold little liquidity. ${ }^{3}$

\footnotetext{
$\overline{2}$ Failure through loss of liquidity can be very rapid and can also rapidly lead to loss of capital. We develop these points in the text.

3 This is why the notion that there needs to be international regulation of liquidity is, at the least, not completely thought through.
}

It is useful to set out why failure through loss of liquidity is usually more rapid than that through loss of capital. When a bank has started to lose capital, it has generally been through persistent bad lending. Banks usually diversify so that no one loan can bring down the bank. Hence banks which lend badly crumble away rather than collapse. An example of this is Midland Bank, which through a series of bad investment decisions became weaker and weaker until it was taken over by HSBC in 1992. Failure through liquidity can come even from a rumour-the bank is short of cash - and people hasten to withdraw their funds before other people withdraw theirs. A classic example of a liquidity inspired run on a bank is that on Down, Thornton, and Free in 1810. That bank was one which Henry Thornton, the famous writer on banking, was a junior partner, and how it was almost brought to collapse before lunch by a run that started in the morning is vividly described in Forster [2]. ${ }^{4}$

Price stability is therefore not enough for financial stability. It may reduce failure through loss of capital, but its effect on loss of liquidity is one would expect in general modest. A particular institution, the lender of last resort, is accepted as being important in that context. The reason is that while the lender of last resort does not lend without taking acceptable collateral, ${ }^{5}$ by lending to firms which can offer such collateral it ensures that panic in consequence of one bank's failing does not spread. Banks which do not have significantly impaired capital are therefore not brought down by running out of liquidity, and what one hopes is the greater part of the banking system is thus protected.

Hence the hypothesis is a two part one. First, the greater is the change in the price level from year to year, the greater will be the number of bank failures, and these will largely be through loss of capital. ${ }^{6}$ This hypothesis we regard as well established - see Schwartz and the numerous references therein. The second argument in a way reverses the sequence of the previous one. This argument is that if we have financial stability the banking system is stable. (Not necessarily individual banks.) And if the banking system is stable, then the money supply will be stable unless disturbed by the action of the authorities. It is possible in principle to examine also whether the money supply is

\footnotetext{
${ }^{4}$ The failure was averted by a most ingenious manoeuvre on the part of Thornton. This too is described in Forster's book. The bank eventually failed, after Thornton's death, in the panic of 1825 .

5 It must be emphasised that this does not support the often repeated claim that the LoLR lends only to solvent institutions. All that is required to get funds is that the institution has collateral to offer in exchange. It may still become insolvent subsequently. See Hawtrey [3].

${ }^{6}$ This number will be smaller for any price level change in the presence of a lender of last resort than it is without one.
} 
significantly disturbed, against the background of a stable banking system, by changes in the cash holding behaviour of the public, or of the banks themselves. However, in this paper we focus on the behaviour of the authorities, both because of data limitations and because we can rely on the work of Cagan [4] for the USA, which showed that all but modest money supply fluctuations were due to changes in the base. Hence our conclusion is that financial stability makes monetary stability easier to achieve. The authorities have less to react to, and so the base becomes more stable. ${ }^{7}$

To summarise, monetary stability promotes financial stability, and financial stability promotes monetary stability.

After that brief summary of the hypothesis and its interdependent justifications, it is necessary next to consider what is meant by the price level and what is meant by financial stability.

\section{Concepts and data}

As David Mayes frequently emphasised, with regrettably little influence on political or regulatory discussion, in the last crisis British banks were brought down not by their investment banks, but by bad real estate lending.

The British experience is that while real estate booms often occur at times of inflation, they can also occur at times when inflation is low and stable. But the central bank cannot stabilise a subset of the price level-monetary policy has at most a temporary effect on relative prices. What can be done about such booms, and indeed if anything can or should be other than ensuring that banks which fall prey to them can fail in an orderly fashion, is a topic outside the domain of monetary policy and thus outside that of this paper. Future work on the connection between booms and busts in asset prices and bank failures could yield interesting results.

We are concerned, however, with the stability of widely accepted measures of the general level of prices. This is connected with the definition of financial stability that we use and with our defence of that definition.

There are choices to be made over what is meant by price stability and what by financial stability.

In recent years, there have been claims that central banks, when focussing on price stability, should concern themselves not just with the stability of goods and services prices, but also with that of asset prices. This is argued in Alchian and Klein [5] and disputed in, for example, Allen

\footnotetext{
$\overline{7}$ It is important to avoid misunderstanding to emphasise that we do not consider that the authorities in any sense targeted the base. We use it simply as an unambiguous measure of their actions.
}

and Wood [6]. But important as that discussion may be, it is not relevant for the present purpose, as no central bank has, so far at least including up to and throughout the era of inflation targeting, actually tried to target such prices, although there has been mention of their serving as an indicator of the state of the economy or of inflation expectations.

Accordingly, then, our discussion of the concept of financial stability we use is against a background of central banks targeting a fairly broad measure of prices, including and dominated by consumer prices.

Here some brief historical observations are useful. The first concern with financial stability appeared, so far as is known, in 1798, when Francis Baring described what had happened to the British banking system on the outbreak of the wars with France, and described what he saw as the appropriate response on the part of the Bank of England [7]. The response that he prescribed was aimed at stabilising the banking system; that was the exclusive focus of his concern and recommendation. Subsequent writersnotably Joplin [8], Thornton [9], and a little later Bagehot [10] — set out why his recommendation was both correct and essential, and in consequence both of these arguments and of the pressure of events the Bank of England accepted the responsibility for stabilising the banking system in the event of a sudden surge in the demand for liquidity. ${ }^{8}$ It accepted the responsibility of being available to be lender of last resort. It had thus implicitly defined what $i t$ meant by financial stability.

This definition remained unchallenged both in Britain and elsewhere until the late twentieth century. (The Banca d'Italia, for example, explicitly citing Bagehot, accepted the responsibility in 1910.) But in recent years, the term has been broadened, used almost promiscuously. One might say that it had become a make-work project. A review and discussion of this is to be found in Allen and Wood [6] and the following paragraphs draw on that paper.

There are several aspects to the financial stability of an economy. Some, indeed most, are not within the domain of the central bank. The legal framework matters-the bankruptcy code and how creditor friendly it is matters, to give an important example. Noting this is important not least because it highlights the abiding presence of tradeoffs. In this case, the more creditor friendly is the code the fewer will be the risks taken and hence in turn one would expect less innovation and slower growth. The stability comes at a cost. But the choice of code is not a matter for the central bank; for it, the code is a given. The same goes for regulatory rules, market conventions, official information provision, and the infrastructure of the financial

\footnotetext{
${ }^{8}$ See Capie [11] and Wood [12] for detailed elaboration and citations on these points.
} 
system. All these can be important (though what is done is not necessarily beneficial ${ }^{9}$ ) for financial stability; but they, also, are the background against which the central bank must operate and not something it controls. The central bank can of course contribute to shaping these influences, but it cannot determine them. Nor can it choose to inject capital into a bank, or, a fortiori, the banking system, for it will not have the capital. Such action is a matter for government. That still, however, leaves a variety of proposals to be considered.

Some authors maintain that some measure of asset price stability is important; examples are Issing [13] and Foot [14], both of whom argue to that effect. But there are problems. Bubbles cannot always be identified at the time, and, even supposing they are so identified, often central banks can do little about them. Further, while bubbles may lead to resource misallocation they are not of themselves financial instability, although they could lead to it by weakening financial institutions.

The implicit notion underlying that proposal is that stability of asset prices is desirable; but that is not selfevidently true. Asset prices embody expectations about the future, and these expectations can change. Preventing or dampening asset price changes that embody changed expectations would lead to resource misallocation (on the basis of what is known at the time, and the fact that mistakes are numerous because expectations are sometimes wrong is not relevant).

The often-expressed desire for asset price changes to be slow rather than rapid is similarly misconceived. How can it be achieved? By a body of market participants slow to recognise change? How can that be good? By official intervention to slow market movements? That would socialise some losses, and that is not a self-evident good.

Others assert that allocative efficiency is an important aspect of stability. For example, in Haldane et al. [15] we find, "...financial instability could be defined as any deviation from the optimal saving-investment plan of the economy that is due to imperfections in the financial sector." That definition is plainly not operational. Further, even if one admits that it in principle is operational, is there any deviation too small to count as financial instability? And what is the optimal saving-investment plan? For most economies there is not even an attempt to construct it, and in those that have tried, such as the Soviet Union in the past, the only result has been to demonstrate the idea's impossibility in practice. Nor do Haldane et al. define "imperfections in the financial sector". They mention "missing markets", but as Demsetz shows in his classic

\footnotetext{
9 For example, the spread of "best practice" by regulators makes banks more homogeneous and thus more liable to experience common shocks, which affect the whole system.
}

1969 paper [16], it is desirable for many markets not to exist, as constructing them would costs more than the sum of any hypothetical benefits.

In sum, no notion of financial stability (so far as use of the central bank's powers extend) can be defended except that arrived at by the Bank of England, on the advice of Joplin, Thornton, and Bagehot_-it must act as Lender of Last Resort.

It must do so in situations of financial crisis, a crisis being defined best in the words of Anna Schwartz in her famous 1986 paper [17].

A financial crisis is fuelled by fears that means of payment will be unobtainable at any price and, in a fractional reserve banking system, leads to a scramble for high powered money.... In a futile attempt to restore reserves, the banks may call in loans, refuse to roll over existing loans, or resort to selling assets. No financial crisis has occurred in the USA since 1933, and none has occurred in the UK since 1866.

\section{The test and the data}

Our basic data series are from Capie and Webber [18]. The periods of particular interest are 1820-1870; 1870-1912; 1920-1970; and 1970-2012. These periods are of interest for, being, respectively, a series of crises followed by the adoption of lender of last resort; then a period of stability; then another one, but depression overseas although stability at home; and then a period with two crises and the crumbling of the Bretton Woods system.

The basic hypothesis that with the adoption of, and commitment to, the lender of last resort role by the Bank of England, the base became less volatile, because the components of the money multiplier became more stable after that adoption. Hence the base is expected to be less volatile in every one of our periods than in the first. And, less strongly, we would expect that it became somewhat more volatile, though still less than in the first period, in the fourth.

\section{An overview of the data and the context}

Before turning to the details is useful to give an overview of the historical context-political as well as economicfrom which the data are drawn.

The long period that we cover in this paper, from 1800 to the present day, ranges over most of the kinds of economic/financial/monetary experiences that are encountered in the modern economy. There are differences in the exchange rate regime, and in price level paths, in inflationary and deflationary phases; there are different periods 
of financial stability and of instability. There are, of course, changes in economic cyclicality in the length and severity of the business cycle. And there were periods, some of them long, of war. We give a brief outline of this experience to prepare the reader for the data analysis that follows.

Our starting point for this brief survey is 1700 to show how the Bank gradually evolved. In the eighteenth century the Bank, founded in 1694, grew to dominate the financial world. There was a metallic standard in place that gradually became a de facto gold standard, the responsibility for which the Bank of England implicitly assumed. The century was one of unrelenting war (with France). The financial system was in its infancy but a banking system had emerged with as many as about 800 banks in the country by the end of the century. There was clear instability in the period as was evidenced early on in the South Sea Bubble of 1720 , though there is nothing until the 1780 s that we would recognise as a financial crisis. There were banking failures throughout.

The eighteenth century ended with a huge disruption to the system in the Revolutionary/Napoleonic Wars with France. In 1797, the gold standard was suspended and not restored until 1821 . Where the eighteenth century had been a long period of relative price stability with a slight tendency for the price level to decline the period from the 1790s onwards was one of inflation and of exchange-rate depreciation.

After 1815, with the expectation of a return to the gold standard, prices after a brief sharp depression, returned to a stable trend and that remained more or less the case until the 1870s - a flat trend with a steady cycle around it. However, and of some interest, these were years of financial instability. This whole period from 1815 to 1870 was punctuated with financial crises with one in every single decade.

In the course of the nineteenth century, the banking system had developed greatly. Branch banking grew. Discount brokers that had appeared early in the century became discount houses, a key element in the operation of the system. And the Bank of England had evolved to a point where it, at least implicitly, accepted its role as the lender of last resort. Something else that should be said is that there was very little in the way of regulation. Entry into banking was open. There was no capital or other requirements. Lending was not restricted.

With these elements in place, financial stability became the norm. The banks had learned their business and arrived at their desired balance sheet structures. The Bank of England was the lender of last resort. There was little regulation. The Discount Houses provided a buffer between the banks and the Bank. The gold standard was in place. However, there then followed a long period of declining prices from the 1870 s to the 1890 s. This was largely and paradoxically brought about by the success of the gold standard. More and more countries adopted the standard and the need for gold reserves outstripped their availability and the shortage led to a fall in money supply and in prices. An upturn in prices returned in the mid-1890s when new gold discoveries allowed an expansion in the monetary base.

World War I changed everything. The gold standard was suspended. There was a financial crisis. War finance led almost immediately to inflation. Debt soared. In 1920, the world looked dramatically different to that of 7 years earlier. The post-war world was full of greater uncertainty. There was a period of floating exchange rates and then a move to a different gold standard, a gold exchange standard, for a short period before that too was abandoned in 1931. Thereafter Britain had a managed rate until after 1945. The interwar years were characterised by greater cyclicality in the business cycle, by gentle deflation in the first decade and then gentle inflation in the second decade. The banking system remained remarkably stable throughout. There were of course some failures as there had always been.

After World War II, there were major changes. Exchange controls that had been introduced in wartime were kept in place. Price controls, also a legacy of war, were slowly removed. But many of the other controls of wartime, explicit or informal, remained and some were extended. This applied to the banking sector such that the period from the 1940s to the 1970 s can be said to have been one of financial repression. There were controls on the scale of and the direction of bank lending. And for most of the period there was a block on raising new capital. The new exchange rate regime that came with Bretton Woods was one of pegged exchange rates, that is fixed but adjustable rates. That lasted until the beginning of the 1970s. Inflation began to appear in the 1950s and to be seen to accelerate by the end of the 1960s.

In the period from the war until the beginning of the 1970s, there were no recessions of the old kind. There were instead cycles in the growth rates. That changed again after the 1970s when there were falls in output rather than falls in the growth of output. And inflation returned with a vengeance. It reached its worst ever levels for Britain in the mid-1970s. There was financial instability again too for the first time since the mid-nineteenth century.

Attacks on the sources of these problems led to a period of considerable stability. Inflation was stable. There was financial stability. The exchange rate floated. But there were deep-lying problems, and these gave rise to the greatest financial crisis of all time in 2007/2008 when the banking system was at threat of collapse without the taxpayer. 


\section{The behaviour of the base across time}

Monthly observations on $M 0$ are available from 1845 , and these form the basis for our primary analysis of the volatility of money growth. Figure 1 plots the annualised percentage growth rate of monthly $M 0$, defined as $1200\left(\log M 0_{t}-\log M 0_{t-1}\right)$. Annualised percentage growth rates are used for consistency with further analyses presented below. The last decade of observations (2006-2016) are depicted in a separate pane because of the shift in magnitude of the growth rate during the initial years of this period.

Columns (1) and (2) of Table 1 report means and standard deviations of monthly money growth for the complete sample period and for various sub-periods based on the discussion of the previous sections. Column (3) reports the average conditional standard error for the same sub-periods calculated from an ARMA-GARCH model fitted to the complete monthly money growth series (for details, see the Statistical Appendix). The complete series of conditional standard errors from which these means are calculated is

M0 annualised monthly growth (\%)

1845 - 2005

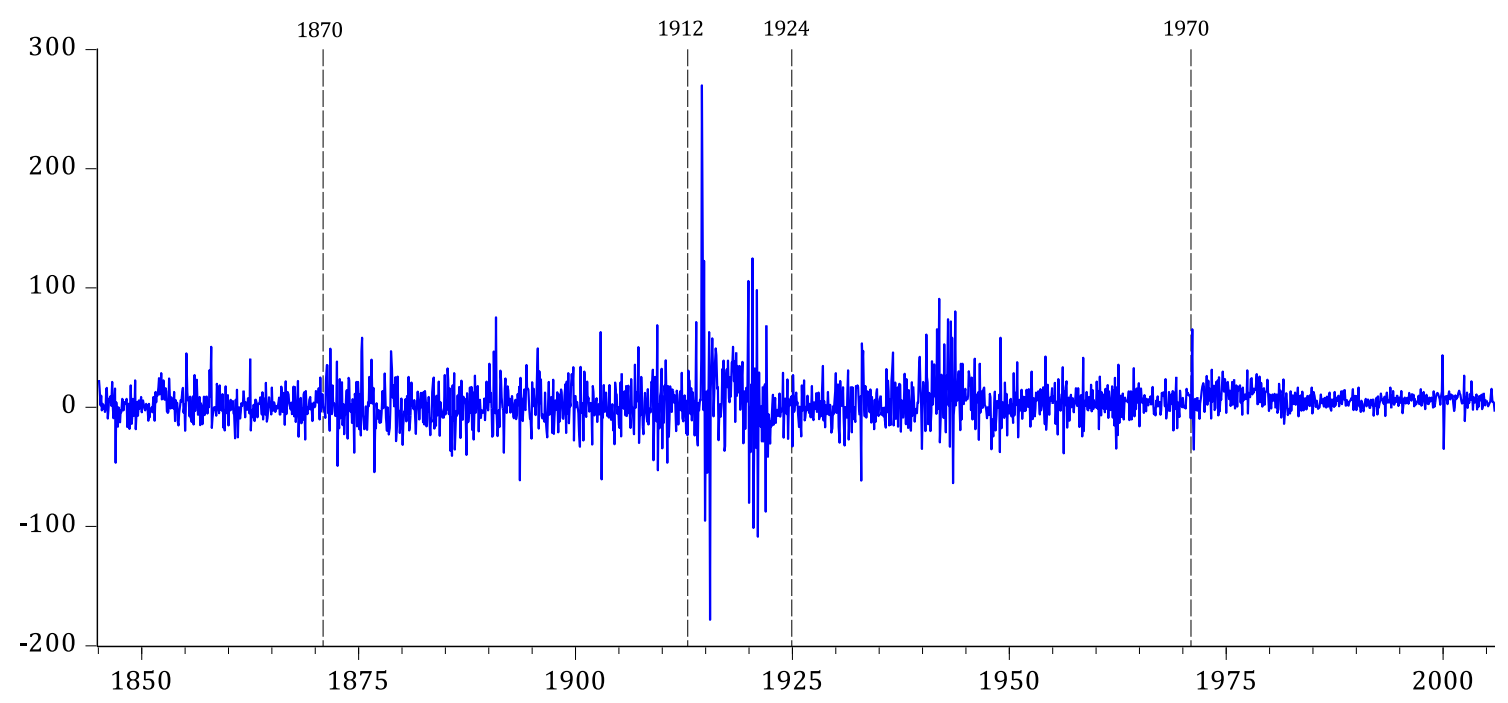

M0 annualised monthly growth (\%)

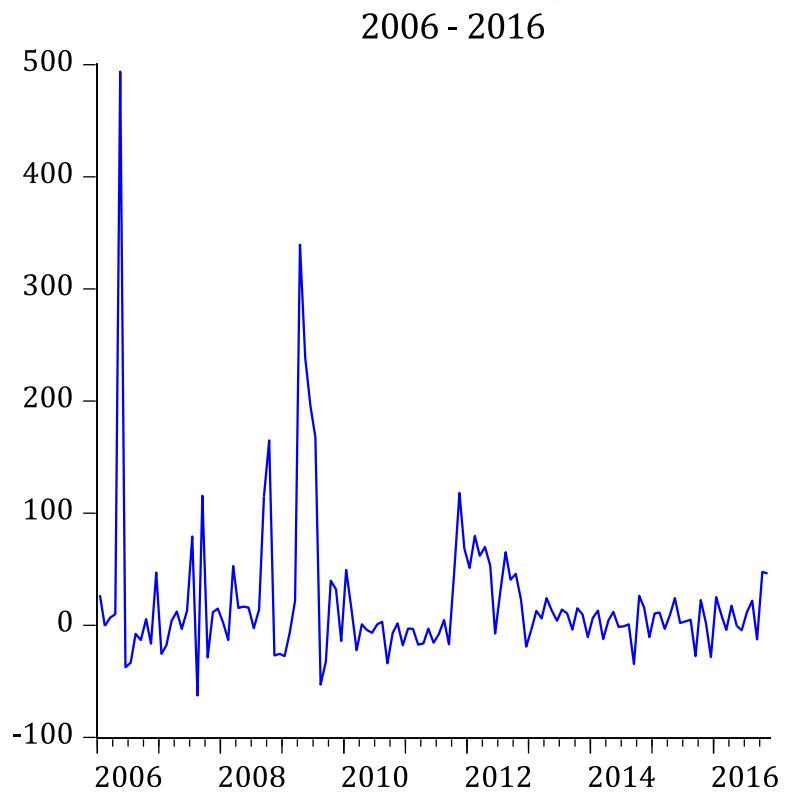

Fig. 1 Monthly growth of $M 0$ (annualised per cent): 1845-2016 
Table 1 Monthly (annualised) M0 growth: 1845-2016

\begin{tabular}{llllll}
\hline & (1) Mean & (2) s.d. & (3) Average conditional s.e. & (4) CV1 & (5) CV2 \\
\hline $1845-2016$ & 5.03 & 25.21 & 20.42 & 0.20 & 0.25 \\
$1845-1870$ & 1.80 & 11.21 & 13.08 & 0.16 & 0.14 \\
$1871-1912$ & 1.12 & 18.18 & 20.20 & 0.06 & 0.06 \\
$1913-1924$ & 7.83 & 44.83 & 40.64 & 0.17 & 0.19 \\
$1925-1970$ & 4.31 & 16.85 & 17.61 & 0.26 & 0.24 \\
$1971-2005$ & 6.90 & 8.50 & 11.56 & 0.81 & 0.60 \\
$2006-2016$ & 21.36 & 66.19 & 55.17 & 0.32 & 0.39 \\
$1971-2016$ & 10.39 & 33.87 & 22.11 & 0.31 & 0.47 \\
\hline
\end{tabular}

s.d.: standard error

Average conditional s.e.: as calculated from AR-GARCH model

$\mathrm{CV} 1=$ mean/s.d.: coefficient of variation

$\mathrm{CV} 2=$ mean/average conditional s.e. shown in Fig. 2, from which the major periods of "volatility turbulence" are seen to occur in the 1913-1924 and 2006-2016 sub-periods. Because volatility may be related to the mean growth rate, columns (4) and (5) report coefficients of variation (mean divided by standard deviation/average standard error) for the various sub-periods.

Mean monthly money growth was smallest for the period up to 1912 and highest from 1971 onwards, particularly for the last decade from 2006. The standard deviations and average conditional standard errors mirror each other, as do the coefficients of variation (CV), which provide a measure of volatility relative to mean growth (a small CV represents high relative volatility). Focusing generally on the latter, we see that, although the period up to 1912 had low average money growth, it had high relative volatility, leading to small CVs. Indeed, a low CV is also found for
1913-1924, although both mean growth and volatility were higher than in earlier years. The period from 1925 to 1970 saw mean growth and volatility, and hence, CVs, close to those computed for the entire sample period, while from 1971 to 2005 volatility was the lowest on record, leading to high CV values. As we have seen, for the last decade both mean growth and volatility were historically high, so that CVs lie in the middle of the range of relative volatility values.

As a robustness check, the calculations were repeated using the annual growth rate of the monthly $M 0$ series, defined as $100\left(\log M 0_{t}-\log M 0_{t-12}\right)$, and the growth rate of the annual $M 0$ series, which is available from 1790. Figure 3 shows the former series and Fig. 4 the conditional standard error calculated from an ARMA-GARCH model fitted to it (again see the Statistical Appendix for details).

M0 annualised monthly growth (\%) Conditional standard error

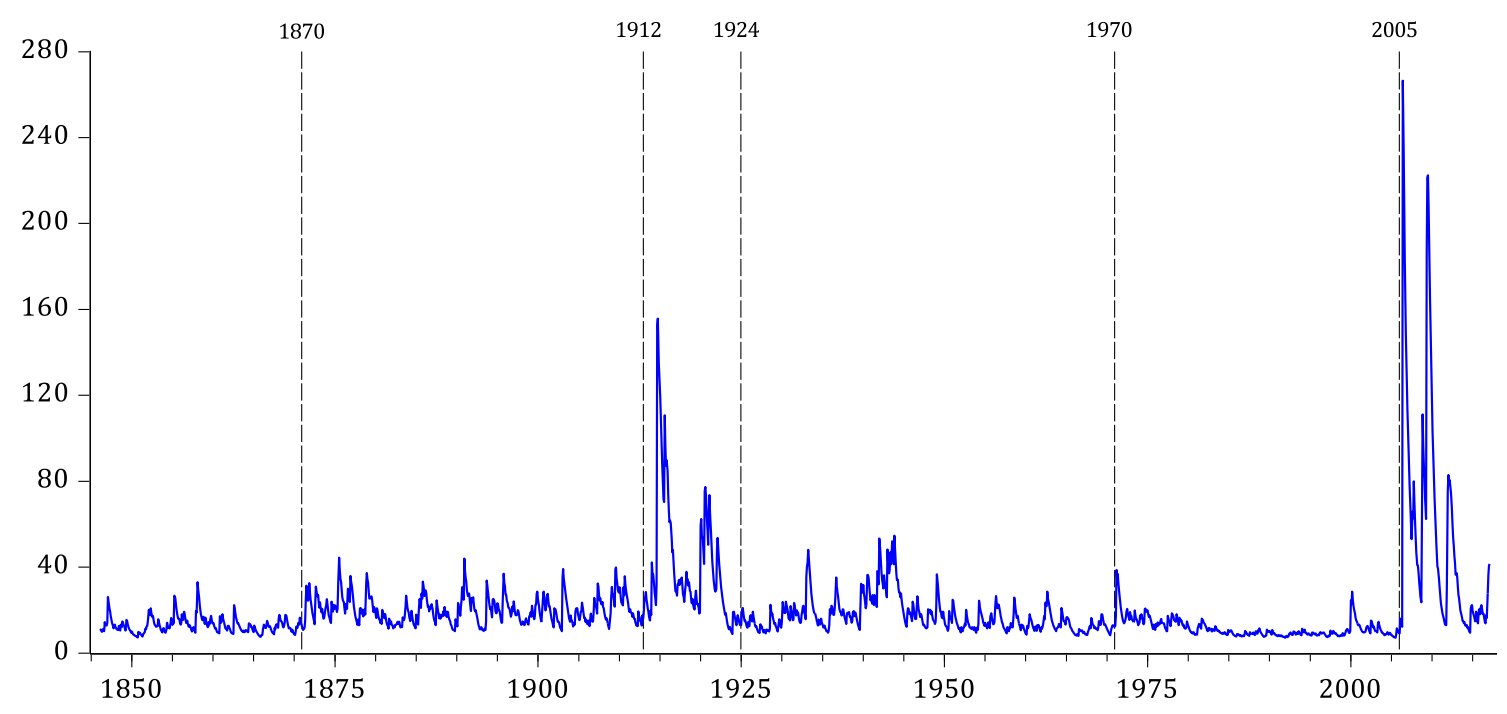

Fig. 2 Conditional standard error of annualised monthly $M 0$ growth calculated from an ARMA-GARCH model: 1845-2016 
Annual growth of monthly M0 (\%)

$1845-2016$

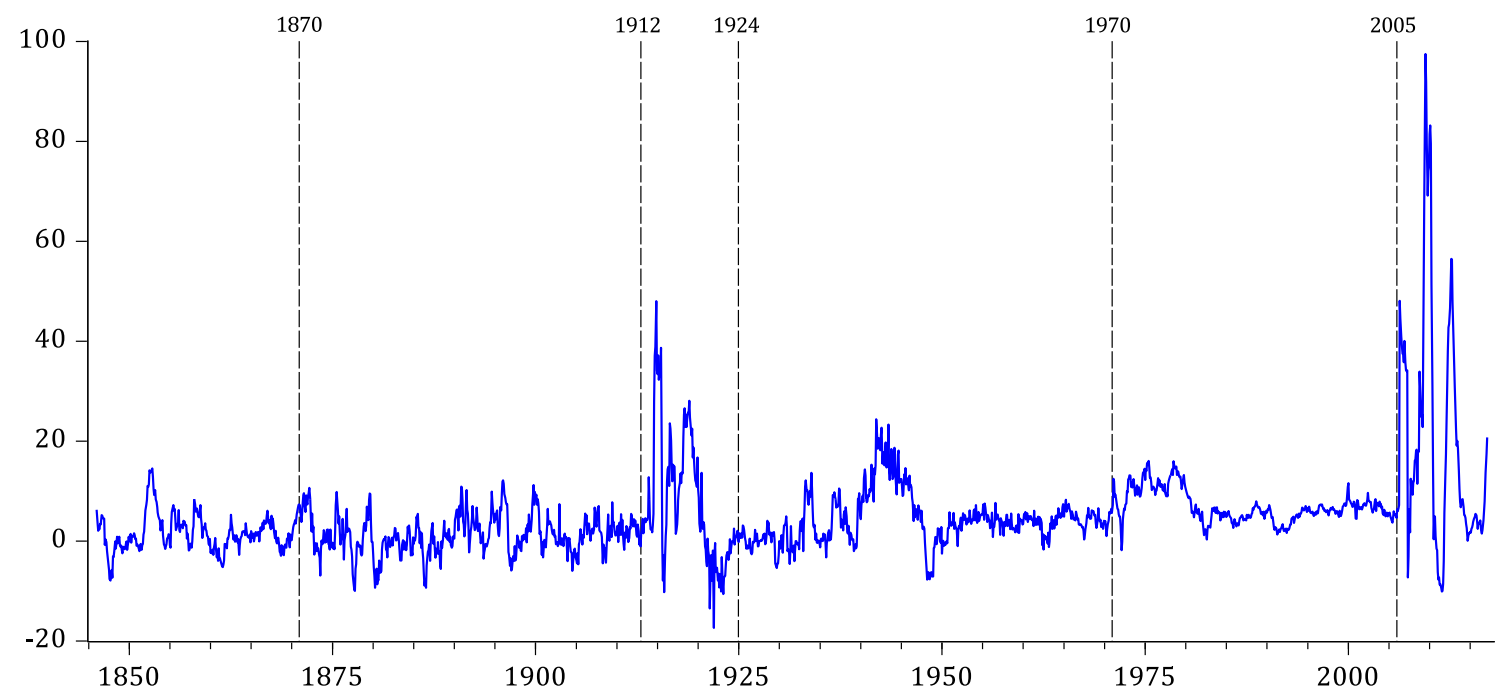

Fig. 3 Annual growth of monthly $M 0$ (per cent): 1845-2016

Annual growth of monthly M0 (\%)

Conditional standard error

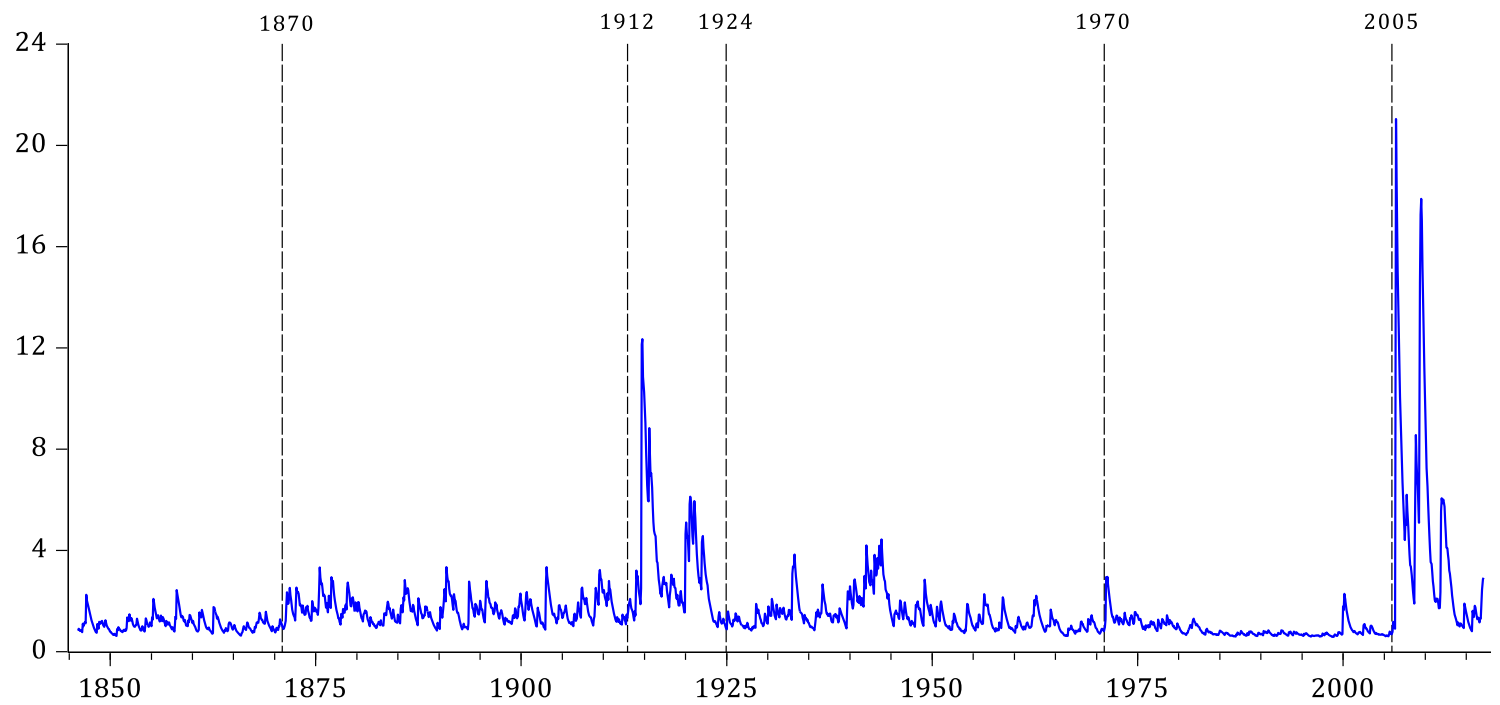

Fig. 4 Conditional standard error of annual growth of monthly $M 0$ calculated from an ARMA-GARCH model: 1845-2016

Table 2 presents the various volatility related calculations obtained using this series. While the mean growth rates across the sub-periods are similar to those reported in Table 1, the standard deviations and average conditional standard errors are necessarily much smaller due to the twelfth differencing of the data. Consequently, the CVs are larger than those shown in Table 1 but their relative magnitudes across the sub-periods are essentially the same, thus supporting the conclusions drawn from that table.
Figure 5 shows the percentage growth rate of the annual M0 series for the entire period from 1790 to 2015, while Fig. 6 shows the conditional standard error calculated from an ARMA-GARCH model fitted to this series (again see the Statistical Appendix for details). Similar patterns to the monthly data are clearly observed from these figures. Table 3 reports the volatility-related statistics subsequently computed. These confirm the conclusions drawn from the monthly data. Relative volatility is highest (low CV) during 
Table 2 Annual growth of monthly M0: $1845-2016$

\begin{tabular}{lcrlll}
\hline & (1) Mean & (2) s.d. & (3) Average conditional s.e. & (4) CV1 & (5) CV2 \\
\hline $1845-2016$ & 4.95 & 9.29 & 1.66 & 0.53 & 2.98 \\
$1845-1870$ & 1.60 & 3.69 & 1.09 & 0.43 & 1.47 \\
$1871-1912$ & 1.25 & 3.91 & 1.65 & 0.32 & 0.76 \\
$1913-1924$ & 7.50 & 12.93 & 3.32 & 0.58 & 2.26 \\
$1925-1970$ & 4.29 & 5.51 & 1.44 & 0.84 & 2.98 \\
$1971-2005$ & 8.50 & 3.17 & 0.88 & 2.18 & 7.85 \\
$2006-2016$ & 20.27 & 24.26 & 4.47 & 0.84 & 4.53 \\
$1971-2016$ & 10.14 & 13.49 & 1.75 & 0.75 & 5.79 \\
\hline
\end{tabular}

s.d.: standard error

Average conditional s.e.: as calculated from AR-GARCH model

CV1 = mean/s.d.: coefficient of variation

$\mathrm{CV} 2=$ mean/average conditional s.e.

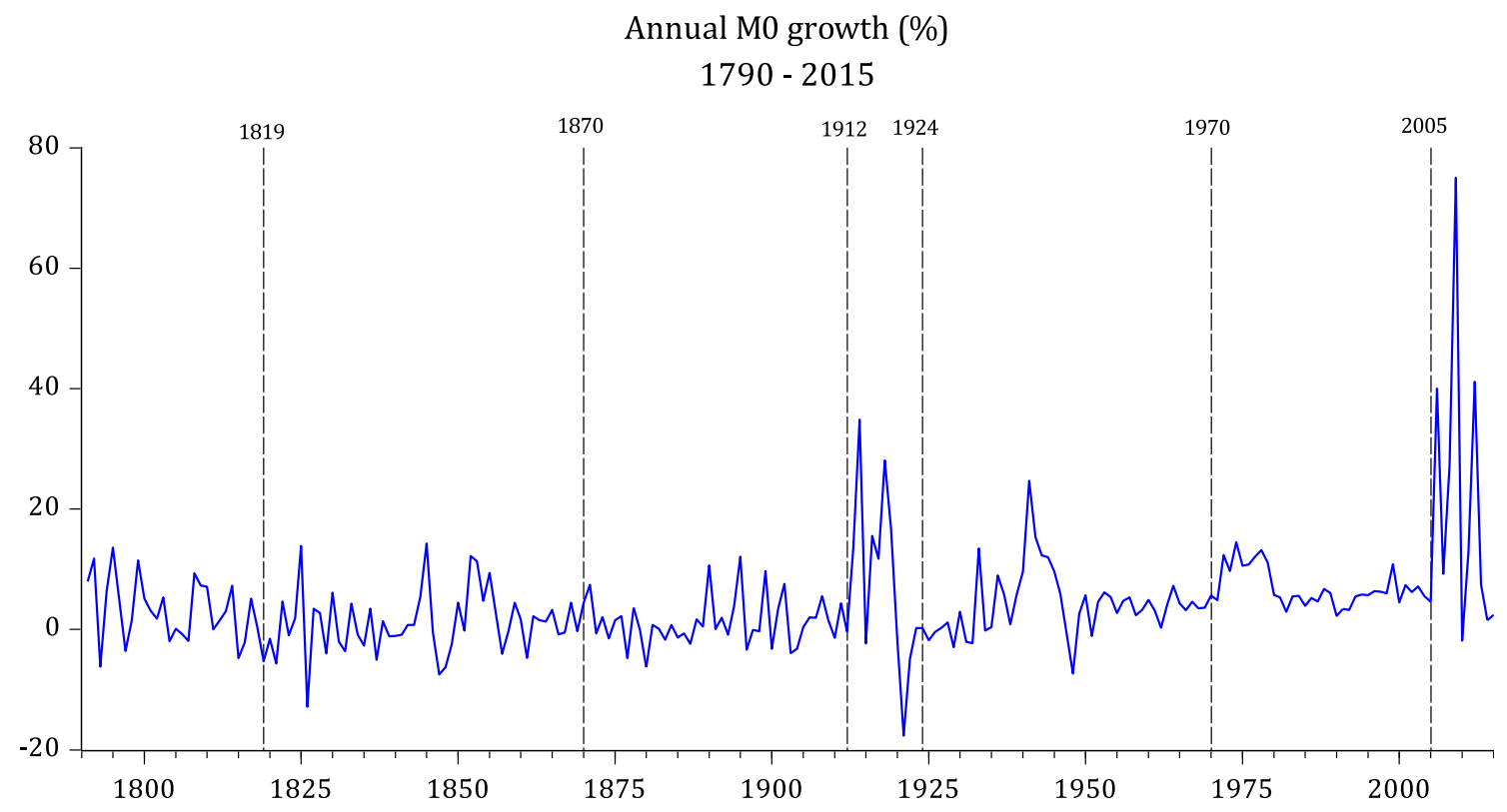

Fig. 5 Annual percentage $M 0$ growth: 1790-2015

the 1820-1912 period and at its lowest (high CV) from 1971 onwards. Before 1820 and between 1913 and 1970, relative volatility was not excessive (middling CV) and close to overall volatility, although the 1913 and 1924 period was characterised by both high growth and high volatility.

It may be asked whether these changes in the behaviour of the base are due not to the emergence of the lender of last resort and consequent financial stability, but to other factors. But what could these other factors be? The price level behaved more or less as desired for a good part of the period, so the outcome of policy (if policy is the right word to use in the context of the years before 1950 or so) was what was desired. The behaviour of the base showed the Bank was having to do less than in the first period to achieve that outcome. Was it stability in the outside world that allowed this? Certainly in the interwar years, this can be ruled out. Likewise, events outside the UK in our second period do not suggest a period of unblemished stability.

Accordingly, we argue that the reduced volatility was a consequence of financial stability as produced by the Bank of England's adoption of the role of Lender of Last Resort to the British banking system.

This leads us to a two-part conclusion. 
Annual M0 growth (\%)

Conditional standard error

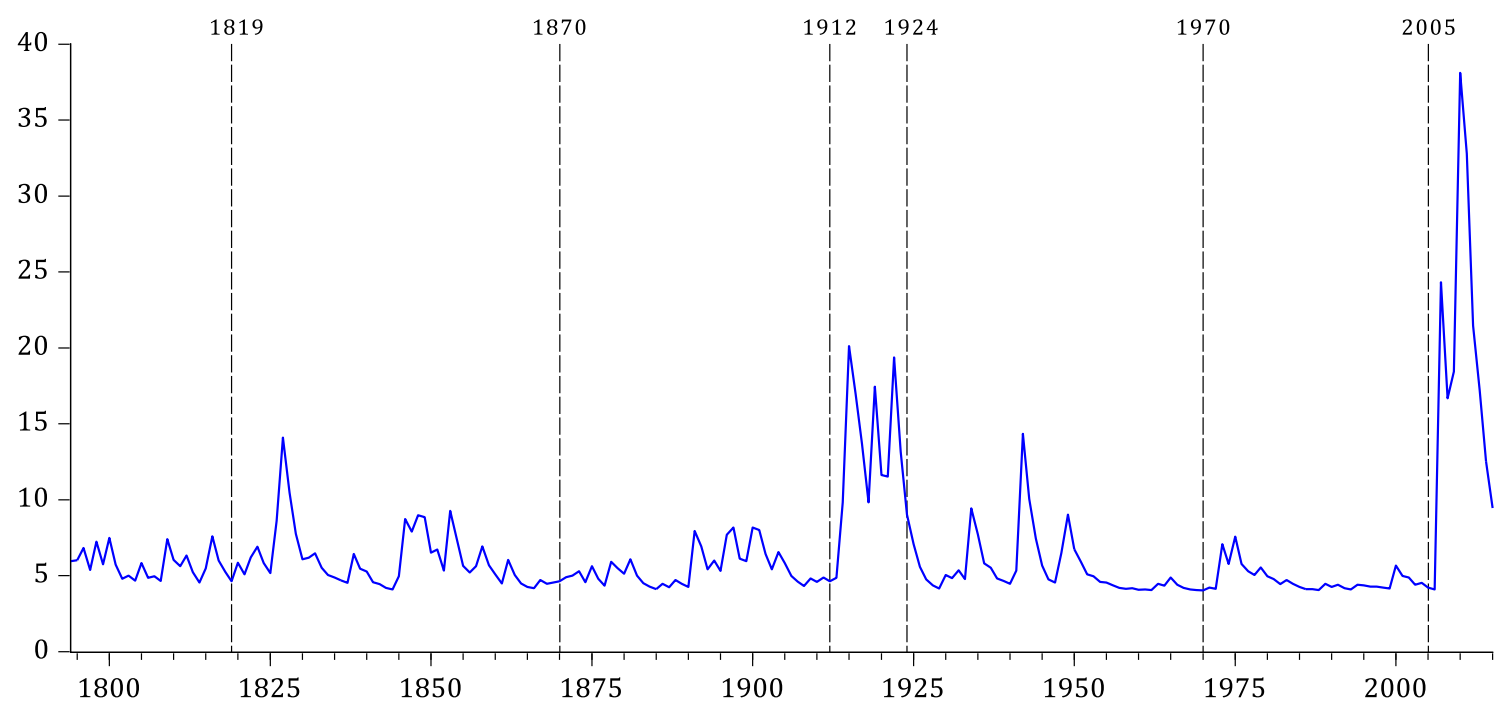

Fig. 6 Conditional standard error of annual $M 0$ growth calculated from an ARMA-GARCH model: 1790-2015

Table 3 Annual $M 0$ growth: 1790-2015

\begin{tabular}{lccccc}
\hline & (1) Mean & (2) s.d. & (3) Average conditional s.e. & (4) CV1 & (5) CV2 \\
\hline $1790-2015$ & 4.20 & 8.60 & 6.57 & 0.49 & 0.64 \\
$1790-1819$ & 3.01 & 5.30 & 5.74 & 0.57 & 0.52 \\
$1820-1870$ & 1.20 & 5.25 & 6.07 & 0.23 & 0.20 \\
$1871-1912$ & 1.17 & 3.98 & 5.47 & 0.29 & 0.21 \\
$1913-1924$ & 7.84 & 14.91 & 13.12 & 0.79 & 0.60 \\
$1925-1970$ & 4.30 & 5.45 & 5.46 & 0.53 & 0.79 \\
$1971-2005$ & 6.90 & 3.14 & 4.74 & 2.20 & 1.46 \\
$2006-2015$ & 21.50 & 24.40 & 19.50 & 0.88 & 1.10 \\
$1971-2015$ & 10.14 & 12.93 & 8.02 & 0.78 & 1.26 \\
\hline
\end{tabular}

s.d.: standard error

Average conditional s.e.: as calculated from AR-GARCH model

$\mathrm{CV} 1=$ mean/s.d.: coefficient of variation

$\mathrm{CV} 2=$ mean/average conditional s.e.

\section{Conclusions}

First, we argue, on the basis of analysis and evidence above, that monetary and financial stability are indeed symbiotic. Monetary stability, via its effects on banks' balance sheets, promotes financial stability. Financial stability, by stabilising the components of the money multiplier, facilitates the achievement of monetary stability.

The second part of our conclusion follows from the observation that we use financial stability in a particular and traditional sense. The various other suggested uses for the term need not lead to that conclusion. Indeed, there have been suggestions (e.g. Forbes, [19]) that the broadening and increasing complexity of the tasks of central banks has impeded the maintenance of financial stability. A conclusion on that must await further work. But to repeat, the traditional role of the central bank as Lender of Last Resort poses no such conflicts. Surely there is a case for reducing the burden of complexity on central banks.

Open Access This article is distributed under the terms of the Creative Commons Attribution 4.0 International License (http://crea tivecommons.org/licenses/by/4.0/), which permits unrestricted use, distribution, and reproduction in any medium, provided you give appropriate credit to the original author(s) and the source, provide a link to the Creative Commons license, and indicate if changes were made. 


\section{Statistical Appendix}

The AR-GARCH model found to be the best fit to the annualised monthly $M 0$ growth series is, with $x_{t}$ denoting $1200\left(\log M 0_{t}-\log M 0_{t-1}\right)$,

$$
\begin{aligned}
x_{t} & \left.=\sum_{i=1}^{12} \hat{\alpha}_{i} s_{i, t}-\begin{array}{c}
1.238 \\
(0.329)
\end{array}\right) \log \hat{\sigma}_{t}^{2}+\sum_{j=1}^{12} \hat{\beta}_{j} x_{t-j}+a_{t} \\
\hat{\sigma}_{t}^{2} & =\begin{array}{c}
10.16 \\
(2.40)
\end{array}+\begin{array}{c}
0.752 \\
(0.022)
\end{array} \hat{\sigma}_{t-1}^{2}+{ }_{(0.040)}^{0.292} a_{t-1}^{2} \\
a_{t} & =\hat{\sigma}_{t} u_{t}, \quad u_{t} \sim t(3.55)
\end{aligned}
$$

This is an AR(12)-GARCH(1,1) model with the logarithm of the conditional variance entering as a regressor in the mean equation along with a set of seasonal dummies $s_{i, t}$. The need for seasonal dummies and a long autoregression up to the seasonal lag 12 is because, although the series has been seasonally adjusted at source, part of the seasonal pattern remains in the data. The errors are best represented by a fat-tailed student's $t$ distribution with 3.55 degrees of freedom. Volatility evolves as a $\operatorname{GARCH}(1,1)$ process, although it is found to be non-stationary so that volatility is very persistent (omitting the last decade of observations reduces the extent of the non-stationarity in volatility considerably, although there is little change in the remaining specification).

Denoting the annual growth rate of monthly $M 0$, $100\left(\log M 0_{t}-\log M 0_{t-12}\right)$, as $y_{t}$, then the following ARMA-GARCH model was found to adequately fit the series:

$$
\begin{aligned}
y_{t}-y_{t-1} & =\begin{array}{c}
0.00084 \\
(0.00028)
\end{array} \log \hat{\sigma}_{t}^{2}+a_{t}+\sum_{i=1}^{21} \hat{\theta}_{t-i} a_{t-i} \\
\hat{\sigma}_{t}^{2} & =\begin{array}{c}
0.064 \\
(0.015)
\end{array}+\begin{array}{c}
0.770 \\
(0.021)
\end{array} \hat{\sigma}_{t-1}^{2}+\begin{array}{c}
0.265 \\
(0.036)
\end{array} a_{t-1}^{2} \\
a_{t} & =\hat{\sigma}_{t} u_{t}, \quad u_{t} \sim t(3.66)
\end{aligned}
$$

Here the long moving average in the mean equation, which, in fact, is of multiplicative seasonal form, is a consequence of the link between $y_{t}$ and $x_{t}$, this being

$12 y_{t}=\sum_{i=0}^{11} x_{t-i}$

The growth rate of the annual $M 0$ series has a much simpler AR(3)-GARCH(1,1) representation, being

$$
\begin{aligned}
x_{t} & =\begin{array}{c}
3.023 \\
(0.624)
\end{array}+\begin{array}{c}
0.350 \\
(0.055)
\end{array} x_{t-1}+\begin{array}{c}
0.281 \\
(0.047)
\end{array} x_{t-3}+a_{t} \\
\hat{\sigma}_{t}^{2} & =\begin{array}{c}
9.40 \\
(4.33)
\end{array}+\underset{(0.411}{0.200)} \hat{\sigma}_{t-1}^{2}+{ }_{(0.217)}^{0.462} \hat{a}_{t-1}^{2} \\
a_{t} & =\hat{\sigma}_{t} u_{t}, \quad u_{t} \sim \operatorname{GED}(0.94)
\end{aligned}
$$

Again the error distribution is fat-tailed, this time being a generalised exponential distribution (GED). The GARCH process is stationary and, as to be expected, less persistent than the monthly model.

\section{References}

1. Schwartz, Anna J. 1988. Financial stability and the federal safety net. In Restructuring banking and financial services in America, ed. W.S. Haraf, 34-62. Washington, DC: American Enterprise Institute.

2. Forster, E.M. 1956. Biography of Marianne Thornton, 1797-1887: A domestic biography. London: Edward Arnold.

3. Hawtrey, R.G. 1932. The art of central banking. London: Longmans, Green \& Co.

4. Cagan, P. 1965. Determinants and effects of changes in the stock of money, 1875-1960. Chicago, for NBER: Chicago University Press.

5. Alchian, A., and B. Klein. 1973. On a correct measure of inflation. Journal of Money, Credit, and Banking 5(1): 173-191.

6. Allen, William, and Geoffrey Wood. 2012. Defining and achieving financial stability. Journal of Financial Stability 2: $152-172$.

7. Baring, Francis. 1797. (Reprinted 1967 by Augustus Kelly) $O b$ servations on the History of the Bank of England and on the Paper Circulation of the Country banks.

8. Joplin, Thomas. 1825. An illustration of Mr Joplin's views on currency, and plan for its improvement. Series of letters to the courier.

9. Thornton, Henry. 1802. An enquiry into the nature and effects of the paper credit of Great Britain (Repromted Augustus M. Kelley, Fairfield, 1978).

10. Bagehot, W. 1873. Lombard Street. New York: Wiley.

11. Capie, Forrest. 2002. The emergence of the Bank of England as a mature central bank. In The political economy of British historical experience, ed. Donald Winch and Patrick O'Brien, 1688-1914. Oxford: Oxford University Press.

12. Wood, Geoffrey. 2000. The lender of last resort reconsidered. Journal of Financial, Services Research 18(2/3): 203-227.

13. Issing, O. 2003. Monetary and financial stability: Is there a tradeoff? In Paper delivered at a conference on monetary stability, financial stability, and the business cycle. Bank for International Settlements, Basle, March 28-29.

14. Foot, M. D. K. W. 2003. Protecting financial stability-How good are we at it? Speech given at University of Birmingham, June 6. Bank of England Mimeo.

15. Haldane, A.G., V. Saports, S. Hall, and M. Tanaka. 2004. Financial stability and macroeconomic models. Bank of England Financial Stability Review 16: 80-88.

16. Demsetz, Harold. 1969. Information and efficiency: Another viewpoint. Journal of Law and Economics 12(1): 1-22.

17. Schwartz, Anna J. 1986. Real and pseudo crises. In Financial crises and the world banking system, ed. F. Capie and G. Wood. Basingstoke: MacMillan.

18. Capie, Forrest, and Alan Webber. 1985. A monetary history of the United Kingdom 1870-1982. London: George Allen \& Unwin.

19. Forbes, Kristin. 2017. Failure to launch. Speech given at London Business School, June. Bank of England Monetary Policy Committee Mimeo. 
Forrest Capie is Professor Emeritus of Economic History at the CASS Business School, City, University of London. His recent books are the commissioned history of The Bank of England (CUP, 2010) and (with G E Wood), Money over two centuries (OUP, 2012).

Terence C. Mills is Emeritus Professor of Applied Statistics and Econometrics at Loughborough University, England, having previously held professorial appointments at City University Business School and the University of Hull, also in England. He has written several books, including Time Series Techniques for Economists (1990) and The Econometric Modelling of Financial Time Series (3rd edition, 2008), and he has edited such works as Monetary and Banking History: Essays in Honour of Forrest Capie (2011) and Time
Series Econometrics, 4 volumes (2015). Terence has also published over 200 articles in books and journals, including the Journal of Economic History, the Journal of the Royal Statistical Society, the Journal of Climate and the International Journal of Body Composition Research, on subjects as diverse as economics, finance, meteorology, climatology and public health.

Geoffrey Wood is Emeritus Professor of Economics at Cass Business School and Emeritus Professor of Monetary Economics at the University of Buckingham. He has advised central banks in several countries and published extensively in monetary economics, financial regulation, and monetary and financial history. He is currently an adviser to several firms, and two pension funds. 